\title{
Through U.S. Eyes: Examining Spanish Multilingual Education Policies*
}

\author{
Ana M. Relaño Pastor \\ Universidad de Castilla-La Mancha. Department of Modern Philology (English Studies) \\ anamaria.relano@uclm.es \\ Laura Mijares \\ Universidad Complutense de Madrid. Department of Arabic and Islamic Studies \\ laura.mijares@filol.ucm.es
}

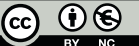

Recibido: 22-04-2010

Aceptado: 08-03-2011

\begin{abstract}
This article offers an overview of the main language education policies aimed at addressing the needs of immigrant background students currently implemented in Spain's multilingual schools. In particular, the article examines the politics of segregation of language immersion programs for newcomers in the Spanish State, as well as their relationship with other language learning programs implemented as part of European initiatives to promote the use of Global English. This study is based on long-term ethnographic research conducted in different schools in Madrid. Adopting a comparative perspective, we also discuss different language programs in U.S. public schools: e.g., English as a Second Language (ESL) programs, bilingual education initiatives, Transitional and Dual Immersion programs. We examine how different educational policies for English language learners in the U.S. might be able to inform Spanish language education policies, forcing us to rethink the current school integration of immigrant origin students in Spain. We conclude with a critical discussion of the lessons we can draw from both cases.
\end{abstract}

Key words: multilingualism; language policy; immigration; education; ethnography; United States of America; Spain.

Resumen. Una revisión de las políticas lingüisticas educativas en España desde la perspectiva estadounidense

Este artículo revisa las principales políticas lingüísticas dirigidas a los estudiantes de origen inmigrante en los centros educativos españoles con una amplia población multilingüe. Adoptando una perspectiva comparativa, el artículo parte de las últimas investigaciones

* Data has been collected as part of the project "Multilingualism in schools: a critical sociolinguistic analysis of educational linguistics programs in the Madrid region" (HUM200764694), directed by Prof. Luisa Martín Rojo and supported by the Spanish Ministry of Science and Education. 
sobre política lingüística desarrolladas en EEUU. Tomando como punto de partida el trabajo etnográfico llevado a cabo en diferentes escuelas de Madrid, se analizan los resultados de las políticas segregadoras que imponen algunos programas de inmersión lingüística para recién llegados en el Estado español. Igualmente, se analiza la relación de estas políticas con otros programas lingüísticos implementados en Madrid como parte de determinadas iniciativas europeas centradas en la promoción del uso del inglés como lengua global. El objetivo es estudiar estas cuestiones desde la perspectiva estadounidense y, por lo tanto, desde el análisis de las diferentes orientaciones en cuanto a planificación de la política lingüística en sus escuelas públicas (entre otros, se parte de los programas de inglés como segunda lengua (ESL) o de las diversas iniciativas de educación bilingüe, como los programas de transición y de doble inmersión lingüística). Por lo tanto, el artículo analiza cómo las diferentes políticas educativas dirigidas a los aprendices de inglés en EEUU pueden arrojar alguna luz sobre el sentido de las políticas lingüísticas implementadas en los centros educativos españoles y, sobre todo, ayudarnos a reflexionar sobre la influencia de dichas políticas lingüísticas en la integración del alumnado de origen inmigrante. Se concluye con una reflexión crítica sobre las lecciones que pueden extraerse del análisis de ambos casos.

Palabras clave: multilingüismo; política lingüística; inmigración; educación; etnografía; Estados Unidos; España.

\section{Summary}

\section{Introduction}

2. Research on Language policy: Language policies and language ideologies

3. Language Education Policies in the U.S.: A Permanent Paradox

4. Immigration and Language Education Policies in Spain: A Monolingual Habitus in a Multilingual Context
5. What Does Our Ethnographic Fieldwork Show?

6. Discussion

Bibliography

\section{Introduction}

The presence of immigrant background students in Spanish schools has increased considerably in the last decade, from 80,587 students in 1998-1999 to 743,696 in $2008-2009 .{ }^{1}$ This represents almost $10 \%$ of the total school population in Spain. In the Madrid region, the percentage rises to 14\%, making Madrid one of the regions with the highest number of foreign students in schools. Despite the visibility of these students in Spanish schools, with newcomers arriving at a rate of 100,000 per year, the general approach to language education for immigrant background students in Spain continues to

1. Statistics on immigrant students collected by the Spanish Ministry of Education refer only to "foreign students". This includes any student whose nationality is different from the Spanish one, regardless of their place of birth. Data is available at http://www.educacion. es $/ \mathrm{mecd} /$ jsp/plantilla.jsp?id=31\&area=estadisticas 
be monolingual and monocultural, grounded in assimilationist ideologies that consider "Spanish only" the key to successful school integration.

In this article, we discuss the main language education policies implemented in Spain's multilingual schools to address the needs of immigrant background students from a comparative perspective, comparing it with the latest research on language policy in the U.S. context. For the particular case of Spain, the article will examine the politics of segregation of language immersion programs for newcomers in the Madrid region, as well as their relationship to other language learning programs implemented as part of European initiatives to promote the use of Global English. Our research in Spain is informed by long-term ethnographic research conducted at different schools in Madrid. We compare the Spanish case with the procedures and results of language planning and language policy approaches carried out in U.S. public schools, such as English as a Second Language (ELS) programs, bilingual education initiatives, Transitional and Dual Immersion programs, amongst others.

Our main goal is to examine how U.S. language policy research may be able to inform Spanish language education policies and programs, forcing us to rethink the current school status of immigrant origin students in Spain. This will be achieved through a revision of the development and implementation of various educational policies for U.S. English language learners, followed by a discussion of current research in language education policies in Spain.

Given the vast scope of language policy research in the U.S., we focus our attention on California, one of the most multicultural states of the U.S. with a long-standing tradition of developing and implementing language policies for culturally diverse students. We compare the linguistic and cultural challenges faced by Californian schools with our long-term ethnographic research in Madrid.

This article is divided in five sections. Section 2 offers a theoretical approach to research on language policy as a distinctive branch of sociolinguistics. Section 3 refers to research on language policies in the U.S. in general, and to California language education in particular. Section 4 critically addresses the language policies implemented in Spain, with specific focus on the Madrid region. Section 5 briefly sums up the results obtained from fieldwork conducted through two projects ${ }^{2}$ undertaken by the MIRCo research group. ${ }^{3}$ In a final section, this article critically addresses the lessons we can draw from both cases, and offers proposals to rethink current language education policies in Madrid's multilingual schools.

2. These projects are: "Multilingualism in Schools: a Critical Sociolinguistic Analysis of Educational Linguistics Programs in the Madrid Region” (2007-2010)- HUM2007-64694-”, and "A socio-pragmatic analysis of intercultural communication in education: towards integration in schools (2003-2007)-BFF2003-04830", both supervised by professor Luisa Martín Rojo as principal investigator.

3. The MIRCo group is committed to researching multilingualism in all its linguistic, social, political, economic and educational aspects. Major areas of research include multilingualism in education, human migration and the workplace, and intercultural communication. For more information, visit the MIRCo Website: http://www.ffil.uam.es/mirco/index_eng.php. 


\section{Research on Language policy: Language policies and language ideologies}

Language policy (LP), considered a branch of sociolinguistics since the 1950s by Western-trained linguists, deals with how society conceptualizes language and its different linguistic arrangements in various language contact situations. LP is a consolidated field of research that covers the role of language in society. This involves having a clearly articulated view about the nature of language and about language varieties and change, and understanding how power is represented and reflected in language policies at all levels of the social structure and social processes (Ricento, 2006:19). Whether at school, the workplace, the home or in community spaces, language policies influence what languages or linguistic varieties we speak, the level of linguistic appropriateness, the values attached to some languages, the scale ("good/ acceptable" or "bad/unacceptable") according to which individuals measure the use of language in society, and so on. Other pioneers in the field of LP distinguish three components of the language policy of a speech community: "its language practices; its language beliefs or ideology; and any specific efforts to modify or influence that practice by any kind of language intervention, planning or management" (Spolsky, 2004: 5). We should understand language education policies therefore as a reflection of how society regulates the relationships and interactions of different ethnic groups within a country. Without a clear viewpoint about the nature of phenomena such as bi- or multilingualism, language maintenance, language shift, or even, more generally, linguistic diversity, educational language policies are prone to be ineffective for the communities of speakers they aim at.

The definition of language policy implies the idea of what a government does officially, through legislation, legal processes, executive action, or by any other means to: "a) "determine how languages are used in public contexts, b) cultivate language skills needed to meet national priorities, or c) establish the rights of individuals or groups to learn, use, and maintain languages". In addition, it also captures "the idea of the government regulation of its own language use, including steps to facilitate clear communication, train and recruit personnel, guarantee due process, foster political participation, and provide access to public services, education, proceedings, and documents" (Crawford, 2004: 56). As Crawford points out, language policies are measures to regulate the use of languages and their users, and as such are deeply connected with ideologies about non-dominant languages in society and the speakers of non-official languages. Some of these ideologies have to do with whether linguistic diversity should be considered a threat or an asset to the nation, and whether, if it constitutes a threat, linguistic diversity should be contained or even eliminated through restrictive legislation, or whether it should be conserved as an asset and exploited in the national interest by ensuring civil and political rights for newcomers.

Language ideologies have been subjected to many definitions in the last decades. Blommaert (2006: 241), in his review of the field, defines language ideologies as "socially and culturally embedded metalinguistic conceptualizations of 
language and its form." Kroskrity $(2000 ; 2004)$ insists on the omnipresence of language ideologies in society, not necessarily originating from the ruling class, but also including implicitly or explicitly speakers' assessment of the role of language and communicative practices in society. These evaluative judgments are based on thoughts, values, and beliefs attached to languages, linguistic varieties, and their speakers. In sum, "language ideologies are beliefs, or feelings, about languages as used in their social worlds" (Kroskrity, 2004: 498). In addition, Kroskrity (2004: 501-509) agrees on the multidimensional nature of language ideologies as a field of study, pointing out five layers of significance crucial to understanding how pervasive language ideologies are among speakers in any society, and how they generally relate to language policies. The scope of language policy and language ideology research is very broad, capturing very diverse issues, such as the perception of language and discourse among different cultural groups, the plurality of language ideologies in society according to different social divisions (class, gender, elites, or generations), opposition to and contestation of dominant language ideologies in society, individuals' awareness of local language ideologies; how language ideologies mediate between social structures and forms of talk, and the role of language ideologies in policy-makers' decision regarding which languages to use in the making of national identities and which to consider as marginal in the nation-state.

Overall, language ideologies are deeply ingrained in language policies, and, more specifically, in language education policies adopted in every country to deal with linguistic and cultural diversity. They constitute the foundations of "folk linguistics", acquired from friends, relatives, media, community leaders, or schoolteachers, and are popularized through reinforcement by society's dominant institutions (Crawford, 2004: 62). For example, the language maintenance at school by immigrant background students is very much dependent on the integration policies a country decides to implement (Mijares, 2006). However, the lack of a clear conceptualization of what to do with immigrants' languages at school, and therefore the lack of a clear terminology to refer to migrant languages in the Spanish case, can be understood as the result of a lack of concern for well-designed education policies addressing multilingualism as a result of immigration. While the co-official languages - Catalan, Basque and Galician - are commonly called lenguas cooficiales, the terminology used for immigrant languages, by contrast, remains very elusive. The most common term adopted by administration is lenguas de origen, a literal translation of the term used in the French context, langues d'origine.

Ruiz (1984: 17), an expert in language planning, proposes another approach that shows the interrelationship between language ideologies and language policy by suggesting that the concept of orientation refers to those ideological frames that "delimit the ways we talk about language and language issues". Ruiz distinguishes three basic orientations to language planning and language policy:

- Language-as-a-problem emphasizes the complications created by linguistic diversity in society, including how language constitutes a social problem 
that cannot be separated from poverty, illiteracy, ethnic conflicts, truancy, unemployment, or crime.

- Language-as-right builds on principles of human rights, social justice, democracy, and citizenship, guaranteeing the recognition of linguistic diversity in public domains, equal access to schools, courts, hospitals, workplace, and other public institutions.

- Language-as-resource treats linguistic diversity as an invaluable asset in society that cannot be wasted. This approach values languages as part of society's cultural capital and recognizes the benefits of language conservation. Regarding language education policies for immigrant background students, this approach fosters language programs that value each of the languages and linguistic varieties students bring to school as learning resources that empower students in the classroom.

These orientations, while present in governmental language policies, should not be assigned a direct causal role as if any government decides at a particular moment to adopt a language-as-a-problem alternative over the language-asresource one (Crawford, 2004: 74). As this scholar suggests language policy decisions are typically more complex, less about language directly and more about underlying social and political conflicts.

In the following sections, we discuss the state of language education policies in the U.S., focusing our attention on the state of California, one of the most multicultural and controversial states in relation to linguistic diversity and school integration policies. We argue that the evolution of language policies for English learners in the U.S. sheds light on the manner in which the Spanish administration addresses the educational needs of immigrant students. We draw on ethnographic sociolinguistic research, conducted by the MIRCo team in different Madrid schools in the last decade, to show how linguistic practices in classroom interactions produce and reproduce the existing social order regarding the integration of immigrant communities in Spain. We conclude by discussing the future that lies ahead for newcomers in Spanish schools, and the lessons we can draw from both cases to improve the education of students from an immigrant background.

\section{Language Education Policies in the U.S.: A Permanent Paradox}

With a total population of over 308 millions (U.S. Census Bureau, 2010), the U.S. constitutes a multilingual mosaic consisting of "more than 380 categories of single languages or language families" (Census Brief, 2003). In Census 2000, as in the two previous censuses, the U.S. Census Bureau asked people aged 5 and over if they spoke a language other than English at home. ${ }^{4}$ Among the

4. Here, we refer to data provided by Census 2000 given that Census 2010 is currently rolling out state data on an ongoing basis. For more information, visit the U.S. Census Bureau Website at http://www.census.gov/. 
262.4 million people aged 5 and over, 47.0 million (18\%) spoke a language other than English at home, reaching over 55 million in the last year (almost $20 \%$ nationwide). The rationale for including this question related to the need to speak English to perform daily activities and to communicate effectively with "government and private service providers, public officials, medical personnel, schools, and other service providers" (Census Brief, 2003: 9). According to the Census Brief (2003: 9-10), "those who do not have a strong command of English and who do not have someone in their household to help them on a regular basis are defined as being 'linguistically isolated'." This report goes on to define "linguistically isolated households" 5 as the ones in which "no person aged 14 or over speaks English at least 'very well", and "linguistically isolated persons" as "any person living in a linguistically isolated household." Once a household is defined as "linguistically isolated" any member will be classified as linguistically isolated, including children under 14 who may speak English.

A brief look at statements like these may suggest the U.S. has a strong commitment to linguistic diversity, but upon analyzing them more closely a linguistic phobia for languages other than English becomes apparent. The definition of linguistic isolated households shows the ideology of a deficient view on linguistic diversity and the denial of the practice of daily communication in languages other than English in the U.S. Who decides when English is spoken "very well"? What about the multiple linguistic repertoires of ethnically diverse families in the U.S., who are able to easily switch back-and-forth between English and other languages? What about heritage or community language learning that fosters cultural affinity and recovers emotional ties with speakers' relatives and older generations? How can someone be linguistically isolated in the U.S. when "more than 380 categories of single languages or language families" form part of the linguistic mosaic?

These questions are situated at the core of the big contradictions underlying the relationship of the U.S. with its multilingual population. The paradox in a nation of such size and demographic complexity is that the U.S. does not have a comprehensive national language policy (Keller, 1983; Molesky, 1988; Crawford, 2004). Instead, the U.S. has developed language policies as "ad hoc responses to immediate needs or political pressures in different states" (Crawford, 2004: 55). In other words, there is no consensus on how to better educate English learners in the U.S.

5. These terms will no longer be present in the U.S. Census Bureau's reports starting in 2011 due to the efforts made by the American Anthropological Association (AAA) experts on Language and Social Justice from the Committee for Human Rights and the Society for Linguistic Anthropology. According to the newsletter released by AAA on May 2, 2011, the U.S. Census Bureau writes, "We have changed the terminology to one that we feel is more descriptive and less stigmatizing. The phrase that will appear in all new products will be Households in which no one 14 and over speaks English only or speaks a language other than English at home and speaks English 'very well." More information can be found at: http:// www.aaanet.org/issues/press/upload/U-S-Census-Bureau.pdf. 
In addition, although English is not mentioned as the official language of the U.S. in the Constitution, there are 30 states that have passed English-only laws, effectively making English the official language. This includes some of the most multicultural states, such as California where Proposition 63 declared English the official language of California in $1986 .{ }^{6}$ Molesky (1988) agrees that the linguistic silence of the Constitution allows for two different interpretations. On the one hand, it may suggest that the Constitution encouraged tolerance of linguistic diversity and allowed room for as many languages as there are speakers in the U.S. On the other hand, the lack of explicit mentioning of any language also leaves room for restrictionist arguments. These two traditions, characterized by Kloss (1977: 285) as the "American bilingual tradition" and the "one country, one language" tradition, are still at the forefront of current debates regarding the education of English language learners (ELLs). As Molesky (1988: 35) clearly states, "throughout U.S. history, periods of tolerance for linguistic diversity have alternated with periods of linguistic restrictions on or even persecution of newcomers, especially if the newcomers are visibly different, non-Anglophone, non-Northwest-European immigrants."

\section{Language Education Policies for English Learners}

English language learners (ELLs), sometimes also referred to as LEP or "students with limited English proficiency", represent one of the fastest growing segments of the K-12 student population in the U.S.7 In the state of California, the number of ELLs reached 1,515,074 in the 2008-2009 academic year. Among the 56 languages identified as languages spoken in Californian schools, the percentage of Spanish-speaking students learning English approximates $85 \%$, followed by 2,5\% Vietnamese students. According to the California Department of Education, Latino students continue to share the highest enrollment in Californian public schools (49\%), followed by $28 \%$ of Whites and $7 \%$ of African-Americans. ${ }^{8}$ In this article, we focus on the different educational options for English learners in one of the most controversial state, considering the multicultural diversity of its population, the number of Spanish speakers, and the linguistic restrictionism of its language policies.

According to U.S. Census Bureau (2009), California has the largest percentage of non-English-language speakers (39\%), closely followed by New Mexico (37\%), Texas (31\%), New York (28\%), Hawaii (27\%), Arizona and

6. For more information about the number of states with active Official English laws, visit the US-English webpage: http://www.us-english.org/view/13. Oklahoma is the latest state that made English the official language on 10 November 2010, which means that all transactions by the state must be performed in English.

7. K-12 refers to Kindergarten to High School Education. Grade 12 corresponds to the graduation year in high school education in the United States.

8. See http://data1.cde.ca.gov/. "Latino", "White" and "African-American" are official labels set by government and administrative agencies, including U.S. Census data, the media, and social institutions to identify ethnic groups in the United States. 
New Jersey (each about 26\%). In 2000, eight states had over one million non-English-language speakers, led by California with more than twice the number of any other state (12.4 million). These figures would lead us to expect that a liberal state like California would provide English learners with a variety of educational options to ease the transition of non-English speaking students into mainstream education. However, in 1998 California passed Proposition 227, a ballot initiative that dismantled most bilingual education programs in California. ${ }^{9}$ Instead, California implemented a single, all-English program, "not normally intended to exceed one school year for English learners throughout the state-regardless of their individual needs, the desires of their parents, or the advice of professionals" (Crawford, 2004: 28). Arizona passed a similar measure (Proposition 203) in 2000, while Massachusetts too passed an English-only law in 2002. ${ }^{10}$

The English-only dominant language ideology combines with anti-immigrant ballot initiatives, such as Proposition 187 "Save our State" (passed in 1994), which denied education and social services for undocumented immigrants in California, and Proposition 209 (passed in 1996), which banned affirmative action programs in Californian Universities. The Elementary and Secondary Education Act (ESEA) proposed by the Bush administration, reauthorized in 2002 as the No Child Left Behind Act (NCLB), is considered the leading federal law affecting education from kindergarten through high school in the U.S. ${ }^{11}$ Researchers have pointed out that this policy is very dismissive of the academic needs of English language learners because it is based on a technical assessment system that mandates uniformity in content, instruction, and assessment. According to Haertel and Herman (2005: 24), this emphasis on school accountability is a key factor negatively effecting "traditionally low performing students-typically economically disadvantaged, language minority, students of color, and students with disabilities."

Bilingual education in the U.S. evolved considerably well in the 1960s and 1970s, when the Bilingual Education Act passed in 1986, until the late 1980s and 1990s, when it started losing public support while the English-only movement gained terrain. ${ }^{12}$ Nowadays, in the post-Proposition 227 era, bilingual

9. More information about Proposition 227 can be found at: http://primary98.sos.ca.gov/ VoterGuide/Propositions/227.htm.

10. For more details about Proposition 203, visit: http://primary96.sos.ca.gov/e/ballot/prop203.html.

11. ESEA is built on four principles: accountability for results, more choices for parents, greater local control and flexibility, and an emphasis on doing what works based on scientific research. For more information about the NCLB Act of 2002, visit: http://www.ed.gov/ nclb/overview/intro/index.html. Information about Proposition 187 can be found at: http:// www.ccir.net/REFERENCE/187-History.html. Information on Proposition 209 is available at: http://vote96.sos.ca.gov/BP/209.htm.

12. The Bilingual Education Act (1968) is the first piece of United States federal legislation regarding minority language speakers. The Bilingual Education Act was eliminated in 2002 when the No Child Left Behind passed. For more information about the Bilingual Education Act (1968), visit James Crawford's Language Policy Website: http://www.languagepolicy.net/. 
education programs and English as a second language (ESL) support continues to exist in Californian schools. ${ }^{13}$ Although teachers and administrators who violate Proposition 227 can be sued by parents and are held personally liable for financial damages and legal fees, parents have the option to sign a waiver allowing their children to receive language support in ESL classes or through a bilingual education program such as the Transitional Bilingual Education program, which offers ESL support on a daily basis and progressively incorporates English instruction. Table 1 presents a summary of the main programs for school-aged English learners in the U.S., including the state of California:

As we can see in Table 1, the options of ELLs range from no support at all to various language programs that help them linguistically in different ways. First, submersion programs offer no linguistic support at all, letting students to pick up English on their own with the goal of eventually fully assimilating into English-dominant society. The underlying language ideology of submersion programs is a deficient view of languages other than English as impediments to school integration. Second, ESL pullout programs share the same ideology but they provide remedial instruction in English for 30 to 45 minutes a day. Students usually feel different from their peers when they are pulled out from their regular classrooms and placed in small groups for tutoring in English. They often internalize the negative perspective from their peers and teachers that their native language constitutes an obstacle to their education. ESL pullout rapidly becomes insufficient as a remedial measure because students spend most of the day sitting in mainstream classrooms without any linguistic support, exposed to incomprehensible input in English.

Third, Structured English Immersion programs started in the 1980s with the decline of Bilingual Education. They emulate French immersion programs in Canada, which had proven successful in cultivating bilingualism among English-speaking students. The difference was that the intention of these programs in the U.S. context was to assimilate language learners into a monolingual English environment, contrary to the philosophy of immersion programs in Canada, whose aim was to provide students with the language support necessary to be bilingual. Fourth, Transitional Bilingual Education (TBE) programs are the most common type of bilingual programs in the U.S. Students usually exit the program as they gain enough proficiency in English to be able to follow regular classes. These programs offer different pedagogical options to English learners, from bilingual math or bilingual social studies classes for those

13. The National Association of Bilingual Education (NABE) will celebrate its $39^{\text {th }}$ Annual Conference in February 2010. NABE is the only national professional organization devoted to representing Bilingual Learners and Bilingual Education professionals in the United States. NABE has affiliates in 25 states, including the California Association for Bilingual Education (CABE), and has advocated for bilingualism and English learners living in a multilingual and multicultural society by supporting and promoting policy, programs, pedagogy, research, and professional development that yield academic success, value native language, lead to English proficiency, and respect cultural and linguistic diversity. For more information, visit: http://www.nabe.org/. 


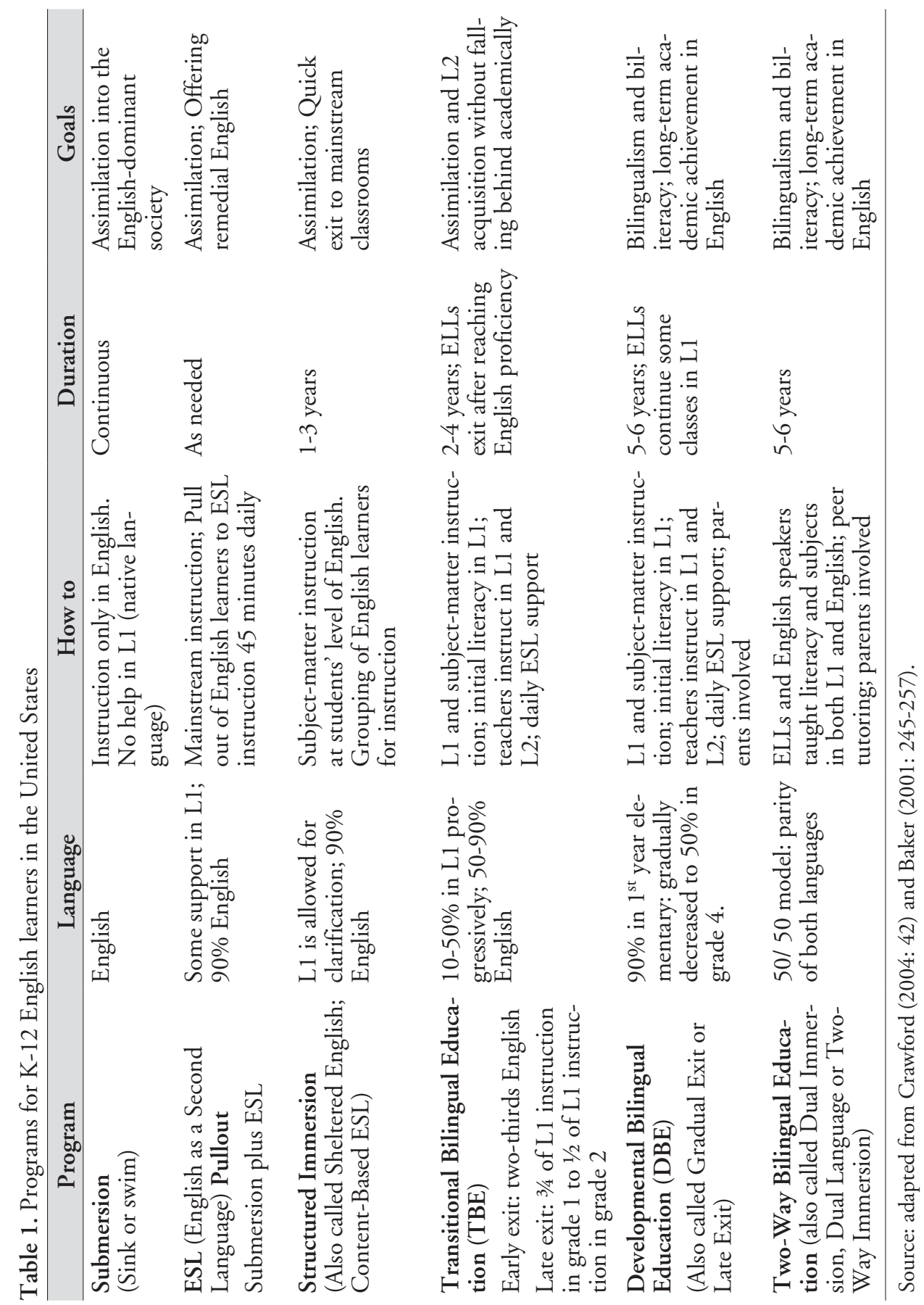


late-arriving English learners to 50\% assistance in L1 for elementary students. Teachers require bilingual teaching credentials in specific subjects, or a general certificate in bilingual education.

There are many similarities between TBE programs and the fifth option, Developmental Bilingual Education (DBE) programs, but the underlying approach to bilingualism and long-term literacy development is very different. While TBE programs aim at speeding up English learners' transition to mainstream classrooms, treating L1 as an obstacle to successful English proficiency (subtractive bilingualism), Developmental Bilingual Education offers an additive approach to bilingualism. The main premise of these programs is that, with a rigorous curriculum, qualified teachers and enough time, English learners can enrich their L1 skills and achieve high academic standards and bilingual fluency. It also involves parents in their children's education by allowing the use of L1 in the classroom, allowing them to help with homework. Finally, the Two-Way Bilingual Education programs, also called "Dual Immersion, Dual Language" or "Two-Way Immersion"14, combine DBE for English learners with foreign-language immersion for learners of Spanish. Dual immersion programs in English and Spanish, for example, have become increasingly popular over the years in the U.S. The Center for Applied Linguistics (CAL) compiled a directory of Two-Way Bilingual Immersion programs in 2003, and identified 271 of these programs in 24 states (Crawford, 2004: 297). For instance, the 50/50 model teaches all subjects in both languages, using the same amount of English and Spanish throughout the program, fostering bilingualism and biliteracy.

Bilingual education has generally been at the centre of controversy in the U.S., in part due to language ideologies about what being bilingual and speaking languages other than English means in the multicultural and multilingual mosaic of the country. Crawford argues that some of the most commonly accepted ideas about bilingual education are fallacies that distort the reality of the linguistic landscape in the U.S. ${ }^{15}$ Prominent among these is the fear that English is losing ground to other languages, that bilingual programs are costly and not needed because the best way to learn a language is through "total immersion", that newcomers are not learning English, or that parents of immigrant children prefer instruction in English and oppose bilingual education programs. These fallacies form all part of the imaginary realm of a monolingual United States. As Ovando (2003: 18) suggests language policy in the U.S. still continues to struggle with "an uneasy balance between unum and pluribus", in a permanent paradox towards linguistic diversity at the turn of the $21^{\text {st }}$ century.

14. These are more acceptable labels among English monolinguals in the United States, who think bilingual programs are for the children of immigrants.

15. For more information, visit Crawford's Language Policy Website at: http://www.languagepolicy.net/. "Ten Common Fallacies about Bilingual Education" can be accessed at: http:// www.languagepolicy.net/articles.html\#be. 


\section{Heritage Language Education and the Politics of Linguistic Recognition ${ }^{16}$}

The turmoil that bilingual education continues to cause among educators and parents of immigrant children in the U.S., together with the "deep values" that persist in a society profoundly English monolingual (Ricento, 1998), which rejects the social and economical value of language maintenance by immigrant communities, contrasts with the major efforts that heritage language education in the U.S. has expended to preserve languages other than English in the country.

The term "heritage languages" in the U.S. refers to languages other than the nationally dominant one, historically associated with the ethnocultural heritage of particular minority populations (Fishman, 2006). According to Wiley (2001), the definition of heritage languages is problematic and the term is at times synonymous of immigrant languages, indigenous languages, and colonial languages, giving a false impression of covering mostly "ancestral" or "primitive" languages. Other terms such as "community languages", or "community-based language learning", common in Canada or in the U.K., are not used that much in the U.S. ${ }^{19}$ However, the connections with home and community are part of other definitions in the field of heritage language pedagogy: "A heritage language speaker is someone who has been raised in a home where a non-English language is spoken, and who speaks or merely understands the heritage language, and who is to some degree bilingual in English and the heritage language" (Valdés, 2000: 1). Similarly, "a heritage speaker is someone who grows up with a certain family language in the home which is different from the dominant language in the country" (Online interview with Dr. Olga Kaga, director of the National Heritage Language Resource Center at the University of California, Los Angeles). ${ }^{18}$

Nowadays, heritage language education faces two main challenges. First, maintaining languages other than English as invaluable language resources in the U.S. Second, halting or reversing the process of language shift with adequate instruction in the heritage language. In the case of Spanish, several researchers have pointed out that loss of Spanish and language shift to English cannot be prevented by the third generation (Zentella, 2005). Spanish heritage language (SHL) programs in post-secondary U.S. institutions continue

16. Heritage language education is a developing multidisciplinary field at the intersection of demography, sociology, psychology, neuroscience, education and other disciplines. Research in the field seeks to identify the unique needs of heritage language learners. The First International Conference on Heritage Languages will take place at the University of California, Los Angeles in February, 2010.

17. According to the nomenclature used by McPake et. al. (2007), it could be useful to think about the adoption of the term "additional languages" to refer to those languages other than the official ones in the European context. This notion is wide enough to include "minority languages", "regional minority languages", "non-territorial languages", and "sign" languages.

18. For more information about this interview, visit the National Heritage Language Resource Center in UCLA at: http://www.international.ucla.edu/languages/nhlrc/news/article. asp? parentid $=93215$. 
to redesign their curricula to accommodate the demands of a growing Latino population with a broad range of bilingual competencies. Beaudrie, Ducar, and Relaño Pastor (2009), for example, conducted a study at a large university in the southwestern United States to assess a complete SHL program with a focus on students' identity and culture. The results of a lengthy survey to assess SHL pedagogy from the students' perspective indicated the need to incorporate SHL student voices into program design and evaluation. Researchers concluded that this was particularly imperative at a time of increased anti-immigrant sentiment and anti-bilingualism (Hill, 1995; MacGregor-Mendoza, 1998; Santa Ana, 1999; Wright, 2007; Zentella, 2003). Students' answers also demanded the strengthening cultural ties with their home and community through meaningful classroom activities that allow students to become active participants in their own community. Overall, heritage language education is committed to linguistic recognition, preservation, and language maintenance of the more than 150 languages used in the U.S. today (Bretch and Ingold, 1998).

\section{Immigration and Language Education Policies in Spain: A Monolingual Habitus in a Multilingual Context}

In Spain, the circumstances surrounding the language use of students from an immigrant background differs considerably from the situation in the U.S. In the first place, Spain does not hold a regular linguistic census that would inform us about the different languages spoken in Spanish society. Neither do schools provide this type of information. However, research undertaken in elementary schools in the Madrid Region identified the use of more than 50 different languages among the school population (Broeder and Mijares, 2003). Among them, researchers found the use of the co-official languages Catalan, Euskera and Galician, but equally the use of prestigious European languages such as English, French or German and a variety of migrant languages, including Arabic, Chinese, Romanian, Tagalog and Polish. The analysis of the comprehensive questionnaire carried out by Broeder and Mijares (2003) in Madrid schools reveals that Spain is indeed a multilingual society, and schools mirror this linguistic situation.

Second, given the lack of a language census in Spain, educational researchers can only rely on statistics about foreign students ${ }^{19}$ provided by the Ministry of Education, but there are usually restricted to geographic criteria such as nationality or continent of origin. ${ }^{20}$ Attempting to figure out how many languages are spoken in Spanish schools based on the nationality figures provided by official educational agencies easily leads to false conclusions, so these statistics must

19. In Spain, the official labeling for students who speak languages other than Spanish and come from abroad is "foreign students". Terms such as "migrant languages" (lenguas inmigrantes) or "ethnic minority languages" (lenguas habladas por las minorías étnicas) are not used in the educational sector, but are now employed by academic scholars.

20. For more information, visit: http://www.educacion.es/portada.html. 
be interpreted with caution. Nevertheless, we can observe a significant presence of different varieties of Latino-American Spanish in 2008-2009 because of 314,000 Latino-American students enrolled in Spanish schools (42\% of the total number of foreign students). Similarly, several European prestigious languages such as English, French or German, together with less prestigious ones such as Romanian, Bulgarian or Ukrainian, were represented by 215,000 students (29\%). Along with European languages, varieties of Arabic as well as Tamazight would be spoken by approximately 127,000 foreign students (17\%), arriving into Spain from Morocco, Algeria and Tunisia. Finally, Chinese linguistic varieties would also have an important representation in Spanish schools, with Chinese students making up for $3 \%$ of the school population.

Third, contrary to the U.S., there is no explicit commitment to linguistic diversity in Spain. In fact, the various linguistic measures adopted by the Spanish administration to meet the needs of immigrant origin students in public schools, demonstrate the existence of several dilemmas and contradictions (Martín Rojo et al., 2003; Martín Rojo et al., 2004; Martín Rojo and Mijares, 2007a). As we show below, the ideologies behind the implementation of language programs for students of diverse ethnic origins in Spain treat cultural differences as a deficit to be remedied rather than an asset for education, fostering assimilation instead of a successful integration (Relaño Pastor, 2009). These policies lack a clear "orientation" toward languages and their role in society (Ruiz, 1984). Following Ruiz's analysis of the different orientations in language planning, namely language-as-problem, language-as-right, and language-as-resource, Relaño Pastor (2009: 260) found with respect to the Spanish case: "(1) an attempt to regulate immigrant origin children's languages, viewed as a problem to be solved by offering Spanish language classes. These classes are usually taught by non-specialists, lack a curriculum, and ultimately segregate immigrant origin students from their peers; (2) There is no contemplation of immigrant origin children's languages as a right to use at regular schools". We argue that this linguistic scenario shows the prevalent monolingual habitus (Bourdieu, 1982) that favors dominant languages and imposes a negative perspective on other languages in Spanish society.

\section{Language Immersion Programs for Newcomers}

In Madrid, educational programs aimed at immigrant background students primarily focus on compensatory education and the implementation of measures geared towards acquiring communicative and linguistic proficiency in the host language. An analysis of the Spanish educational legislation reveals deep contradictions between aims to integrate students' cultural and linguistic diversity and the resources allocated to meeting this goal. More specifically, only programs of a compensatory nature, based on the assumed deficit of children of migrant workers, have been implemented (Martín Rojo et al., 2003). These educational policies, both at State and Regional levels, conceal a vision of diversity as a deficit and students from an immigrant background as 
socially disadvantaged. When reviewing Regional government measures from a linguistic point of view, one can see that the present ideology is largely based on the consideration of children of migrant workers as a-lingual. The educational measures established to allow them to acquire the language of school dismiss their prior linguistic knowledge. This explains why virtually references to community languages in the legislation are scarce, and mainly refer to the possibility of immigrant communities themselves managing programs to maintain the language and culture of origin through governmental agreements with their countries of origin (Mijares, 2006).

The only language policy regarding the children of immigrant communities adopted in Spanish schools are the Spanish Language Immersion Programs for Newcomers, which receive different names in the different Spanish regions: Aulas de Enlace in Madrid; ATAL (Aulas Temporales de Adaptación Lingüística) in Andalusia; Aulas de Acogida in Catalonia. In the Madrid region, for example, the Aulas de Enlace (Liaison Classrooms for Newcomers) is part of the so-called School Welcome Program (Programa de Escuelas de Bienvenida), which started in 2003 as an experimental measure to smooth over the school integration of foreign students in the Madrid Region.

In general, these programs are aimed at students who do not speak Spanish or arrive in the school with with a below-average level of schooling. Students usually remain in these dedicated classrooms 5 to 6 hours a day until they achieve a level of Spanish proficiency adequate to transition into mainstream education. ${ }^{21}$ These programs are aimed at foreign students who are not familiar with the language of instruction, which is standard Spanish (Castellano) in the Madrid Region. Students are also allowed to attend some content subjects classes, typically Gym or Arts and Crafts. In principle, the number of subjects they are allowed to attend during the school year is dependent on the level of language proficiency, but in reality they are at the discretion of a teacher who often decides matters arbitrarily without objective support for the decision (Mijares and Relaño Pastor, 2011).

According to Besalú and Vila (2007), language programs aimed at replacing one's home language with the school language entail important risks that should not be overlooked. These authors remind us that successful bilingual education programs must meet certain requirements to achieve an additive approach to bilingualism. However, several organizational aspects of these programs are inappropriately implemented in Spain, privileging a subtractive approach to bilingualism. The requirements for an additive approach -i.e., qualified and bilingual teachers, and involvement of parents in their children's education - are far from fulfilled in the majority of Spain's linguistic programs directed at children with an immigrant background.

21. Students placed in Aulas de Enlace regulated by the Madrid region are to remain in these classrooms for nine months. However, the time students spend in these classrooms depends on decisions made by the school administration, requiring students to attend longer than expected in some cases. 


\section{Heritage Language Education in Spain}

Although the term "heritage languages" is not used in Spain to refer to the languages spoken by immigrant communities, in this section we discuss similarities and differences between the programs implemented in Spain and the U.S. Whereas in the North-American context migrant languages are named "heritage" or "international" languages (Cummins, 1998), the broader term used in Europe is "immigrant" languages (Extra and Gorter, 2001). Nevertheless, within the Francophone context the broadest term is langues d'origine, both in Canada and Europe (Mc Andrew, 2001). In Spain, heritage language education is not contemplated as part of the national curriculum. From a legislative standpoint, Spain has not followed European recommendations regarding multilingualism, nor has it heeded the reasons for developing educational programs to support language maintenance and linguistic recognition. When analyzing educational legislation, we find that Spanish schools, far from implementing linguistic recognition programs, which in the long term would change the sociolinguistic order of their classrooms by promoting languages other than Spanish, support a compensatory view of language education. For example, several schools in the Madrid region allow the teaching of Arabic after school hours, funded by NGOs or local agencies, but overall there is little encouragement to learn community languages, with the notable exception of Arabic and Portuguese.

Spanish governments have undertaken responsibility for offering support for Arabic and Portuguese in school following agreements signed with the governments of Portugal in the mid 1980s and Morocco in the mid 1990s. These are very similar to the ones signed in the 1970s by northern European countries such as France, Germany or Holland with Morocco, Algeria, and Tunisia. In Spain we find the so-called ELCO programs, Enseignement de la Langue et Culture d'Origine (Mijares, 2006). In the 1980s, immigration policies were based on a system of temporary contracting or guest worker policies, which meant that these programs were responsible for providing the children of these guest workers with the linguistic skills needed for their expected return to their homeland. The community language was taught as an extracurricular subject inside or outside the school timetable. Home languages are taught by Moroccan or Portuguese teachers, who are paid by their respective governments. Although the Spanish Ministry of Education or the regional school boards are responsible for organizing the programs, in reality ELCO programs operate separately. For example, a closer look at the program for teaching Arabic to Moroccan students shows that the program is very community-centered and aims at fostering a community sentiment amongst immigrants, but it is also completely dependent upon the diplomatic relations between Spain and Morocco (Mijares, 2006). Overall, the presence of ELCO programs in Spain is the result of a laissez-faire approach to immigration rather than a commitment to the democratization of an increasingly multilingual, multicultural society. 
In spite of European recommendations regarding multilingualism and the implementation of language programs preserving the languages of migrant communities, ELCO programs in Spain have scarcely modified their aims, application, management or financing. Therefore, their implementation does not modify the dominant linguistic hierarchy that values some languages more than others (Bourdieu, 1982). Similarly, it also upholds a linguistic order based on the instrumental value of languages, as opposed to a value grounded in identity (May, 2004). Overall, the implementation of these programs may end up encouraging forced isolation that would eventually lead to the exclusion of students who are perceived linguistic and culturally different by the educational community.

Finally, the most similar programs to heritage or community programs in the U.S. are those committed to the maintenance of immigrant languages supported by Spanish regional educational boards. In the Madrid region, for example, Arabic and Romanian language courses are offered by members of the Moroccan and Romanian communities, who are granted financial support under the "external compensatory actions". In this scenario, the regional administration provides financial support to non-governmental organizations, who in turn run language programs after school hours at their own discretion.

\section{Global English}

In the last years, Spanish-English bilingual programs have spread across Spanish public schools, with the aim of fostering English as the language of global communication. These programs are known as CLIL (Content and Language Integrated Learning) or AICLE (Aprendizaje Integrado de Contenidos $y$ Lengua Extranjera) in Spanish. ${ }^{22}$ They are recommended by the European Commission to improve the learning of European languages throughout the Member States (Marsh, 2002). Unlike bilingual education in the U.S. or Canada, aimed at the language education of minority children, bilingual education in Spain is explicitly connected with the prestige associated with learning a global language such as English. Bilingual programs in Spanish and any of the languages spoken by immigrant communities are not contemplated in Spanish schools, nor are immigrant background students perceived as bi- or multilingual. As Baker (1993: 347) points out, "there is a tendency to value the acquisition of languages while devaluing the linguistic minorities who have them."

The ideology behind the implementation of Spanish-English bilingual programs in Spain has to do with the dominance of English as a global language or, more precisely, with linguistic imperialism (Phillipson, 1992). According to Phillipson, linguistic imperialism refers to the dominant role of English in

22. According to Marsh (2002), CLIL refers to any dual-focused educational context in which an additional language, not usually the native language of the learners involved, is used as a medium to teach content subjects. 
former colonies; it reflects the way in which language pedagogy has consolidated a hierarchy of languages, with English at the top. Consider the role assigned to English in the European Union as the lingua franca. In August 2003, the European Commission produced a document, Promoting language learning and linguistic diversity: An action plan 2004-2006, with the goal of discussing the excessive focus on English in education and in European society in general. This document contained statements such as "learning one lingua franca alone is not enough" or "English alone is not enough" (Phillipson, 1992: 4). Nevertheless, the perception that English is the most important language to learn at school dominates the debate of language education programs in Spain. As Byram (2007: 13) suggests, the perception between learning English and economic factors is so pervasive that "there is a possibility that the strength of impact of English will lead to the disappearance of a range of languages from the language learning curriculum, especially those which have little apparent marketplace value." This is the case in Spain with some immigrant languages reaching a low level of language vitality (Broeder and Mijares, 2003). In the next section, we discuss the results of our ethnographic fieldwork in several schools in Madrid, including a recent sociolinguistic ethnography of both a Language Immersion Program for Newcomers and a Spanish-English bilingual program in one school.

\section{What Does Our Ethnographic Fieldwork Show?}

The MIRCo team conducted several ethnographically oriented projects in different schools in the Madrid Region (Martín Rojo et al., 2003; Alcalá Recuerda, 2006; Mijares, 2006; Martín Rojo and Mijares, 2007b; Patiño Santos, 2008; Relaño Pastor, 2009; Pérez Milans, 2009; Martín Rojo, 2010), showing that the study of language education policies continuously interacts with how social actors make sense of these policies on a daily basis. For example, these studies point out the dilemmas and contradictions involved in the schooling of migrant children in Spain, and the different educational policies adopted to deal with a culturally and linguistically heterogeneous group of students.

Martín Rojo and Mijares (2007a) and Martín Rojo (2010), illustrate clearly how four different schools in Madrid understand and manage linguistic and cultural diversity through the implementation of specific language education policies for immigrant origin students. In general, the corpus gathered at these secondary schools, which includes field notes, audio and video recordings of classroom interactions, interviews with teachers and students, as well as legislation, teaching material, and other school documents, indicates that the recommendations of school documents such as the Proyecto Educativo del Centro (PEC), outlining how to deal with cultural and linguistic diversity, are understood and transformed by teachers in various ways. While the underlying ideology of such documents is based on a deficient view of students, suggesting the need to compensate for their lack of academic knowledge or 
lack of linguistic skills by being placed in separate programs from mainstream classrooms (e.g., Compensatory Education, Curricular Tracking Programs, and Language Immersion Programs for Newcomers), teachers nevertheless make sense of linguistic diversity and take action in different ways.

The four schools analysed range from a school in the centre of Madrid with 83\% Latin-American students (IES Evangelista ${ }^{23}$ ), to three schools in the south of Madrid (IES Violetas, IES Planetas, and IES Jardines), each with 10-15\% of immigrant students from China, Morocco, Rumania, Colombia, Belarus, Equatorial Guinea, Brazil and Colombia. Each one of these schools approach linguistic and cultural diversity in different ways.

IES Evangelista was categorized as having "a bad reputation" because of the high percentage of Latino-American students (Patiño Santos, 2008), and became a Compensatory School destined for school failure. The main contradictions in this school relate to, on the one hand, students of immigrant origin being grouped together and categorized as "low-achievers" or "difficult students", despite their knowledge of Spanish, and, on the other hand, an overrepresentation of "attention-to-diversity" programs. This school offered two Language Immersion Classrooms for Newcomers, two Compensatory Education classrooms, and two Curricular Tracking (Diversificación Curricular) ones, which did not serve the academic needs of the majority of students who came from different Latino American countries and spoke different varieties of Spanish. Far from promoting the school integration of these students, these educational policies effectively segregated students and contributed to their failing grades.

IES Violetas offers a very clear example of segregation and assimilation of students who speak languages other than Spanish. Similar to ESL students in U.S. schools, students in this school were placed in Language Immersion Classrooms for Newcomers and remained isolated from the rest of students. In this case, an educational language policy aimed at fostering the transition of these students to mainstream classrooms by providing the linguistic skills needed to succeed academically, transformed into a segregationist educational measure that excluded students who spoke other languages (see Perez Milans, 2006).

In the IES Planetas, with $9 \%$ of immigrant origin students, the attentionto-diversity ideology was understood in terms of academic knowledge and school performance. The school created groups of high-achievers and groups of low-achievers to meet students' academic needs, but the low-achievement group consisted mainly of immigrant origin students. According to Alcalá Recuerda (2006), the grouping of students under this criterion shows a deficient view of immigrant origin students and has important repercussions for the categorization of these students as "bad students" who behave improperly and transgress school norms.

Finally, in the IES Jardines, immigrant origin students accounted for almost $10 \%$ of the total school population, including the number of students

23. These names are pseudonyms chosen by the MIRCo team's ethnographers. 
from Latin American countries, who represented a minority. Contrary to the other schools, Jardines was characterized by a laissez-faire educational policy regarding the integration of immigrant origin students. That is, there were no special provisions for students coming from other countries and who spoke other languages other than the Compensatory Education Program. Students placed in these classrooms were isolated from mainstream education. Those who did not master Spanish had to go to a different school to attend the Language Immersion Classes for Newcomers. This laissez-faire approach to diversity resembles the "sink or swim" assimilationist policies adopted in U.S. schools. Immigrant origin students ended up being placed in Compensatory Education classrooms for longer than expected, remaining academically isolated with little prospect of transitioning into mainstream education. The cultural capital that these students brought to school was dismissed, and a shared view of a multiethnic, multilingual collective identity was nonexistent at this school (Rasskin-Gutman, 2007).

Our most recent sociolinguistic ethnography in one school in Madrid where two language programs coexist — the Spanish Immersion Program for Newcomers (Aula de Enlace), aimed at students who do not master Spanish, and the Spanish-English Bilingual Program (Programa Bilingüe)— shows a lack of mutual benefits between both language programs, and the establishment of a distinctive linguistic hierarchy with Spanish at the top as the dominant language immigrant students have to learn, followed by English as the most important foreign language at school, and the languages spoken by immigrant origin students trailing at the end (Mijares and Relaño Pastor, 2011).

\section{Discussion}

This article has offered an overview of language education policies in California with the aim of drawing some lessons that could inform decisions regarding the school integration of immigrant origin children in Madrid.

Despite the evolution of language policy research in the U.S. and the consolidation of heritage language education as a new field of research, we find that the pervasiveness of English-only language ideologies combined with antiimmigrant sentiments remain a challenge for language educators. Even if the U.S. is not the best model of linguistic tolerance and respect for non-dominant languages, it may nevertheless offer insights for current language education policies in Spain.

First, the different language programs for English learners in the U.S. have evolved to better meet the educational needs of these students. Bilingual education is still a thorny issue that fills the pages of prestigious academic journals, but models interested in promoting biliteracy and additive bilingualism by respecting the use of any language as a learning resource in the classroom can enrich the education of language learners. The main lessons to draw from these models is how to better improve current teacher training in bilingual education in Spain, and how to implement bilingual programs in Spanish and 
any of the languages spoken by immigrant background children. Language maintenance needs to be preserved as a precious linguistic resource for the school community.

Second, the Spanish-only dominant ideology in Language Immersion Programs for Newcomers is detrimental for the use of languages other than Spanish. As in the U.S., "sink or swim" language policies have proven to hinder academic success among language learners. Students need to find social spaces of value for their languages at school, and this includes allowing them to use these languages in the classroom. Looking at the U.S. experience, Spain can learn that English-only-centered programs, far from helping to better learn English, often result in complete failure. In the Spanish case, this means that current Spanish-English bilingual programs interested in promoting additive bilingualism must allow the use of Spanish as a learning resource in the classroom, or review the time allotted to the use of each language in the curriculum. Language programs that are more respectful of linguistic diversity have proved to be more effective, not only with respect to English learning, but also in regard to the school integration of students who speak other languages.

Another lesson we can draw from the U.S. case has to do with the design and implementation of heritage or community programs for children of immigrants, which are urgently required in a multilingual society such as Spain. It is important to stress the importance and value of linguistic competences other than regional or prestigious European languages. The development of educational policies that value languages other than Spanish or English also implies a commitment to the implementation of linguistic models consistent with the democratic recognition of all the languages spoken in Europe, not only the national ones, that the Council of Europe supports. If, contrary to this, Spain continues to adopt Spanish-only language education policies, the U.S. Experience teaches us it can result in increased anti-immigrant sentiments that would eventually endanger the academic success and general well-being of Spanish learners.

Overall, the role of migrant languages in strengthening the transition to mainstream education and guaranteeing the academic success of immigrant background students need to be appreciated much more. We have seen that, with the exception of the ELCO programs and language programs offered by NGOs or local associations, the Spanish curriculum continues to be monolingual and monocultural, and displays no serious commitment to linguistic recognition. As our ethnographic research in several schools in Madrid has shown, a deficient view of languages other than Spanish dominates the current language learning practice. Teachers still perceive immigrant background students as lacking the linguistic and academic skills necessary to navigate the education system. Most of the times, the lack of Spanish competence becomes a smokescreen that treats linguistic differences as a liability rather than an asset to education.

Finally, the struggle over a better education for English learners in the U.S. tells us how crucial it is to follow the Council of Europe recommenda- 
tions regarding immigration and multilingualism. Byram's contribution to the executive summary of the document From Linguistic Diversity to Plurilingual Education: Guide for the Development of Language Education Policies in Europe (2007) is an invaluable resource for learning how to value languages other than English in Europe. In a multilingual society such as Spain, the education of Spanish learners starts by recognizing linguistic pluralism as an invaluable resource that should not be wasted.

\section{Bibliography}

AlCalá Recuerda, Esther (2006). Aprendiendo a Comportarse: Normas y Evaluación en la Interacción en el Aula. Tesis Doctoral. Facultad de Filosofía y Letras, Universidad Autónoma de Madrid.

Baker, Colin (1993). "Bilingual Education in Wales". In: Baetens Beardsmore, Hugo (ed.). European Typologies of Bilingual Education. Clevedon: Multilingual Matters, 152-164.

BAKER, Colin (2001). Foundations of Bilingual Education and Bilingualism. Clevedon: Multilingual Matters.

Beaudrie, Sara; Ducar, Cynthia and Relaño-Pastor, Ana M. (2009). "Curricular Perspectives in the Heritage Language Context: Assessing Culture and Identity". Language, Culture and Curriculum, 22 (2), 157-174.

Blommaert, Jan (2006). "Language Policy and National Identity". In: Ricento, Thomas (ed.). An Introduction to Language Policy: Theory and Method. Malden, MA: Blackwell, 238-254.

Bretch, R. D. and Ingold, C. W. (1998). "Tapping a National Resource: Heritage Languages in the United States". ERIC Digest. Washington, DC. Retrieved from: http://www.cal.org/ericcll/digest/bretch01.html.

Broeder, Peter and Mijares, Laura (2003). Multilingual Madrid. Languages at Home and at School. Amsterdam: European Cultural Foundation.

Census Brief (2003). Language Use and English-speaking Ability. U.S. Census Bureau. Available at http://factfinder.census.gov.

Besablú, Xavier and VILA, Ignasi (2007). La buena educación. Libertad e igualdad en la escuela del siglo XXI. Madrid: La Catarata.

Bourdieu, Pierre (1982). Ce que parler veut dire : l'économie des échanges linguistiques. Paris: Fayard.

Byram, Michael (2007). From Linguistic Diversity to Plurilingual Education: Guide for the Development of Language Education Policies in Europe. Council of Europe. Retrieved from the Language Policy Division Website: www.coe.int/lang.

Crawford, James (2004). Educating English Learners: Language Diversity in the Classroom. Los Angeles, CA: Bilingual Education Services.

Cummins, Jim (1998). "The Teaching of International Languages". In: Edwards, John (ed.). Language in Canada. Cambridge: Cambridge University Press, 293-304.

Extra, Guus and Gorter, Durk (2001). "Comparative Perspectives on Regional and Immigrant Minority Languages in Multicultural Europe". In: ExTrA, Guus and Gorter, Durk (eds.). The Other Languages of Europe. Demographic, Sociolinguistic and Educational Perspectives. Clevedon: Multilingual Matters, 1-41.

Fishman, Joshua A. (2006). "Acquisition, Maintenance, and Recovery of Heritage Languages". In: VALDÉs, Guadalupe; Fishman, Joshua A.; CHÁvez, Rebecca and 
PÉrez, William (eds.). Developing Minority Language Resources: The Case of Spanish in California. Clevedon: Multilingual Matters, 1-11.

Haertel, Edward and Herman, Joan (2005). "A Historical Perspective on Validity Arguments for Accountability Testing”. In: HERMAN, Joan and HAERTEL, Edward (eds.). Uses and misuses of data for educational accountability and improvement. Malden, MA: Blackwell Publications, 1-34.

Hill, Jane (1995). "Junk Spanish, Covert Racism, and the (Leaky) Boundary between Public and Private Spheres”. Pragmatics, 5, 197-212.

Keller, Gary. D. (1983). "What Can Language Planners Learn from the Hispanic Experience with Corpus Planning in the United States?” In: Cobarrubias, Juan and Fishman, Joshua A. (eds.). Progress in Language Planning: International Perspectives. Berlin: Mouton Press, 253-266.

Kuoss, Heinz (1977). The American Bilingual Tradition. Rowley, MA: Newbury House.

Kroskrity, Paul (ed.) (2000). Regimes of Language: Ideologies, Polities and Identities. Santa Fe, NM: School of American Research Press.

Kroskrity, Paul (2004). "Language Ideologies". In: Duranti, Alessandro (ed.). A Companion to Linguistic Anthropology. Malden, MA: Blackwell, 253-264.

McAndrew, Marie (2001). Immigration et diversité à l'école. Le débat québécois dans une perspective comparative. Montréal: Les Presses de l'Université de Montréal.

McPake, Joanna et. al. (2007). Valuing All Languages in Europe. Strasbourg / Graz : Council of Europe / European Centre for Modern Languages.

MacGreggor-Mendoza, Patricia (1998). "The Criminalization of Spanish in the United States”. In: KibBeE, Douglas (ed.) Language Legislation and Linguistic Right. Amsterdam: John Benjamins, 55-67.

Marsh, David (2002) (ed.). CLIL/EMILE. The European Dimension. Actions, Trends and Foresight Potential. Jyväskylä: University of Jyväskylä.

Martín Rojo, Luisa. et al. (2003). ¿Asimilar o integrar? Dilemas ante el multilingüismo en las aulas. Madrid: MEC/CIDE.

Martín Rojo, Luisa (2010). Constructing Inequality in Multilingual Classrooms. Berlin: Mouton de Gruyter.

Martín Rojo, Luisa; Nussbaum, Luci and Unamuno, Virginia (2004). "Dilemas de las políticas lingüísticas y su estudio”. Estudios de Sociolingüística, 5(2), 187-189.

Martín Rojo, Luisa and Mijares, Laura (2007a). Voces del Aula: Etnografías de la Escuela Multilingüe. Madrid: CIDE.

Martín Rojo, Luisa and Mijares, Laura (2007b). "Sólo en español: Una reflexión sobre la norma monolingüe y la realidad multilingüe en los centros escolares". Revista de Educación, 343, 93-112.

May, Stephen (2004). "Rethinking Linguistic Human Rights”. In: Freeland, Jane and PATrick, Donna (eds.). Language Rights and Language Survival. Manchester \& Northamptom: St. Jerome Publishing, 35-53.

Mijares, Laura (2006). Aprendiendo a Ser Marroquies. Inmigración, Diversidad Lingüistica y Escuela. Madrid: Ediciones del Oriente y del Mediterráneo.

Mijares, Laura and Relaño-Pastor, Ana María (2011) "Language Programs at Villababel High: Rethinking Ideologies of Social Inclusion”. Journal of Bilingual Education and Bilingualism, 14 (2), 427-442.

Molesky, Jean (1988). "Understanding the American Linguistic Mosaic: A Historical Overview of Language Maintenance and Language Shift. In: McKaY, Sandra Lee and Wong, Sau-ling Cynthia (eds.). Language Diverstiy: Problem or Resource? New York: Newbury House, 29-68. 
Ovando, Carlos J. (2003). "Bilingual Education in the United States: Historical Development and Current Issues”. Bilingual Research Journal, 27(1), 1-24.

Patiño Santos, Adriana (2008). La Construcción Discursiva del Fracaso Escolar: Conflictos en las Aulas. El caso de un centro escolar multicultural de Madrid. Tesis Doctoral. Facultad de Filosofía y Letras, Universidad Autónoma de Madrid.

Perez Milans, Miguel (2009). Modernización, Escuelas Urbanas y Enseñanza de Inglés en la China Contemporánea: Una Etnografía Sociolingüistica Crítica. Tesis Doctoral. Facultad de Filosofía y Letras, Universidad Autónoma de Madrid.

Phillipson, Robert (1992). Linguistic Imperialism. Oxford: Oxford University Press.

Rasskin-Gutman, Irina (2007). "Identidades en Proceso de Construcción: ¿Y Tú Cómo Me Ves?". In: Martín Rojo, Luisa and Mijares, Laura (eds.). Voces del Aula: Etnografías de la Escuela Multilingüe. Madrid: CIDE.

Relaño-Pastor, Ana María (2009). "Policy and Practice in Madrid Multilingual Schools". Theory into Practice, 48 (4), 258-268.

Ricento, Thomas (1998). "National language policy in the United States". In: RiceNto, Thomas and Burnaby, Barbara (eds.). Language and Politics in the United States and Canada. Mahwah, NJ: Lawrence Erlbaum, 85-115.

Ricento, Thomas (2006). "Language Policy: Theory and Practice - An introduction”. In: Ricento, Thomas (ed.). An Introduction to Language Policy. Theory and Method. Malden, MA: Blackwell Publishing, 10-24.

RuIz, Richard (1984). "Orientations in Language Planning”. NABE Journal, 8, 15-34.

RuIZ, Richard (1998). "Orientations in Language Planning”. In: McKay, Sandra Lee and Wong, Sau-ling Cynthia (eds.). Language Diversity: Problem or Resource? New York: Newbury House, 3-25.

Santa Ana, Otto (1999). "Like an Animal I Was Treated': Anti-immigrant Metaphor in US Public Discourse”. Discourse \& Society, 10(2), 191-224.

Sposky, Bernard (2004). Language Policy. Cambridge: Cambridge University Press.

U.S. Census Bureau (2010). Available at http://www.census.gov.

VALDÉs, Guadalupe (2000). "Introduction”. American Association of Teachers of Spanish and Portuguese (Eds.), Spanish for Native Speakers: AATSP Professional Development Series Handbook for Teachers K-12. A Handbook for Teachers. Vol. 1. Fort Worth, TX: Harcourt College Publishers, 1-21.

Valdés, Guadalupe; Fishman, Joshua; Chávez, Rebeca and Pérvez, William (2006). Developing Minority Language Resources: The Case of Spanish in California. Clevedon: Multilingual Matters.

Wiley, Terrence G. (2001). "Policy Formation and Implementation”. In: Kreeft

Peyton, Joy; Ranard, Donald A. and McGinnis, Scott (eds.). Heritage Languages in America: Preserving a National Resource. McHenry, IL: Center for Applied Linguistics and Delta Systems Co., Inc.

Wright, Wayne E. (2007). "Heritage Language Programs in the Era of English-Only and No Child Left Behind”. Heritage Language Journal, 5 (1), 1-26. Retrieved August 10, 2007, from http://www.heritagelanguages.org/

Zentella, Ana Celia (2003). “José Can You See?’: Latin@ Responses to Racist Discourse”. In Sommer, Doris (ed.). Bilingual Aesthetics. New York: Palgrave Press, 51-66.

Zentella, Ana Celia (ed.) (2005). "Building on Strength: Language and Literacy" in Latino Families and Communities. New York: Teachers College Press. 